\title{
KAJIAN KARAKTERISTIK SENSORIS, FISIK, DAN KIMIA FRUIT LEATHER PISANG TANDUK (Musa corniculata Lour.) DENGAN PENAMBAHAN BERBAGAI KONSENTRASI GUM ARAB
}

\author{
STUDY OF SENSORY, PHYSICAL, AND CHEMICAL CHARACTERISTICS OF HORN \\ PLANTAIN (Musa corniculata Lour.) FRUIT LEATHER WITH ADDITION OF VARIOUS \\ ARABIC GUM CONCENTRATION
}

\author{
Tri Astuti $^{1)}$, Esti Widowati ${ }^{1)}$, Windi Atmaka ${ }^{1)}$ \\ ${ }^{1)}$ Ilmu dan Teknologi Pangan, Fakultas Pertanian, Universitas Sebelas Maret, \\ email: triastuti16@gmail.com
}

\begin{abstract}
Fruit leather is one of the processed fruit products, shaped similar to thin sheets with specific consistency and flavor. One of the suitable fruits that can be processed to fruit leather was horn plantain (Musa corniculata Lour.). The aim of this research was to determine the effect of the addition of gum arabic on sensory and physical, and chemical characteristics of horn plantain fruit leather and most acceptable gum arabic concentration addition for consumer. The analysis method used was Completely Randomized Design (CRD) with single factor of the addition of gum arabic. Concentration addition of gum arabic in horn plantain fruit leather was 0,3\%; 0,6\%; and 0,9\%. Based on the analysis result according to the sensory analysis using hedonic test, the addition of gum arabic to the horn plantain fruit leather resulted a significant effect on the parameters of color, texture, and overall, whereas the addition of gum arabic to the horn plantain fruit leather did not have a significant effect on the parameters of scent and flavor. The physical and chemical analysis result of the horn plantain fruit leather with gum arabic addition had significant effect on water content $(12,696 \%-13,775 \%(w b))$ and dietary fiber $(2,7563 \%-5,0825 \%(d b))$, and had no significant effect on ash content $(2,875 \%-2,896 \%$ $(d b))$, water activity $(A w)(0,54-0,56)$, and tensile strength $(4,8449 \mathrm{~N}-5,8125 \mathrm{~N})$. The recommended gum arabic addition to the horn plaintain fruit leather was $0,6 \%$.
\end{abstract}

Keywords: arabic gum, fruit leather, horn plantain

\section{ABSTRAK}

Fruit leather adalah salah satu produk hasil olahan buah-buahan, berbentuk lembaran tipis yang umumnya mempunyai konsistensi dan rasa yang khas. Salah satu buah yang cocok untuk dijadikan fruit leather yaitu buah pisang tanduk (Musa corniculata Lour.). Tujuan dari penelitian ini adalah mengetahui pengaruh penambahan gum arab pada karakteristik sensoris, fisik, dan kimia fruit leather pisang tanduk dan penambahan gum arab pada konsentrasi berapakah yang paling diterima oleh konsumen. Pada seluruh analisis digunakan Rancangan Acak Lengkap (RAL) faktor tunggal yaitu variasi penambahan gum arab. Konsentrasi penambahan gum arab pada fruit leather pisang tanduk adalah 0,3\%; 0,6\%; dan 0,9\%. Berdasarkan hasil analisis menurut sensoris melalui uji kesukaan, penambahan gum arab pada fruit leather pisang tanduk berpengaruh nyata pada parameter warna, tekstur, dan overall. Sedangkan pada parameter aroma dan rasa tidak berpengaruh nyata. Hasil analisis fisik dan kimia fruit leather pisang tanduk penambahan gum arab berpengaruh nyata pada kadar air $(12,696 \%-13,775 \%(\mathrm{wb}))$ dan serat pangan $(2,7563 \%-5,0825 \%(\mathrm{db}))$, tidak berpengaruh nyata pada kadar abu $(2,875 \%$ - 2,896\% (db)), aktivitas air (Aw) (0,54 - 0,56), dan kuat tarik (tensile strength) $(4,8449 \mathrm{~N}-5,8125 \mathrm{~N})$. Penambahan gum arab yang direkomendasikan pada fruit leather pisang tanduk yaitu $0,6 \%$.

Kata Kunci : fruit leather, gum arab, pisang tanduk

\section{PENDAHULUAN}

Buah-buahan merupakan jenis bahan pangan yang memiliki kandungan gizi yang lengkap yang dibutuhkan oleh tubuh manusia seperti karbohidrat, lemak, protein, vitamin, dan kandungan lainnya. Namun pola hidup masyarakat di Indonesia belum memiliki kesadaraan untuk mengkonsumsi buahbuahan. Selain itu perilaku masyarakat yang memiliki kebiasaan mengonsumsi makanan yang praktis mengakibatkan kurangnya konsumsi buah-buahan dalam kondisi segar. Maka dari itu perlu adanya upaya penganekaragaman olahan buah agar dapat diterima dengan baik dan mudah oleh masyarakat Indonesia. Salah satu upaya penganekaragaman olahan buah adalah fruit leather.

Fruit leather berbentuk lembaran tipis dengan ketebalan 2-3 mm (Asben, 2007) dan Nurlaely (2002) mengatakan kadar air fruit leather yaitu 10-20\%, nilai Aw kurang dari 0,7 . Kriteria yang diharapkan dari fruit 
leather adalah warnanya yang menarik, teksturnya yang sedikit liat dan kompak, serta memiliki plastisitas yang baik sehingga dapat digulung (tidak mudah patah) (Historiasih, 2010).

Menurut Yenrina et al., 2009, buahbuahan yang baik digunakan sebagai bahan baku untuk pembuatan fruit leather ialah buah-buahan yang memiliki kadar serat yang tinggi dan memiliki aroma yang khas, salah satunya adalah pisang. Salah satu jenis pisang yang dapat diolah menjadi fruit leather yaitu pisang tanduk. Pisang tanduk merupakan jenis pisang yang diolah terlebih dahulu sebelum dikonsumsi. Pisang tanduk memiliki rasa yang sedikit asam dan memiliki aroma yang kuat. Hal ini yang membuat pisang tanduk cocok untuk bahan baku fruit leather.

Masalah yang sering timbul pada fruit leather adalah plastisitasnya yang kurang baik. Untuk menghasilkan fruit leather dengan kriteria tersebut maka diperlukan bahan pengikat yang diharapkan dapat memperbaiki plastisitas dari fruit leather tersebut (Historiarsih, 2010), yaitu dengan menambahkan hirokoloid. Salah satu hidrokoloid adalah gum arab. Gum arab digunakan untuk pengikatan flavour, bahan pengental, pembentuk lapisan tipis dan pemantap emulsi (Setyawan, 2007). Selain itu gum arab memiliki kelarutan yang lebih tinggi dibandingkan dengan hidrokoloid lain.

Penambahan pemanis berfungsi untuk meningkatkan cita rasa dan aroma, memperbaiki sifat fisik dan kimia, sebagai pengawet. Penambahan bahan pemanis juga dapat membantu pembentukan tekstur kompak dan liat pada fruit leather. Pemanis yang digunakan adalah sorbitol.

Penelitian ini bertujuan untuk memperbaiki plastisitas fruit leather pisang tanduk yang dihasilkan serta mengetahui penambahan gum arab terhadap karakteristik sensoris dan fisik, dan kimia fruit leather pisang tanduk.

\section{Bahan}

\section{METODE PENELITIAN}

Bahan dasar pembuatan fruit leather pisang tanduk adalah buah pisang tanduk segar, gum arab, dan sorbitol. Pisang tanduk segar berasal dari Trenggalek diperoleh dari Pasar
Legi, Surakarta, Jawa Tengah. Gum arab didapatkan dari Toko Kimia Bratachem, Surakarta. Sorbitol (liquid 70\%) food grade teknis diperoleh dari CV Agung Jaya, Yosodipura, Surakarta. Aquadest yang digunakan diperoleh dari Toko Kimia KMA, Surakarta. Semua bahan yang digunakan bersifat food grade sehingga aman untuk dikonsumsi. Bahan kimia yang digunakan uji serat pangan antara lain buffer Na-fosfat, termamyl, pepsin, pankreatin, larutan $\mathrm{HCl}$, ethanol $95 \%$, dan aseton.

\section{Alat}

Pisau, panci steam, loyang, blender (Miyako), cabinet dryer (TEW Tipe IL$80 \mathrm{EN})$, spatula plastik, neraca analitik, gelas ukur, dan sendok, botol timbang, oven (Memmert), penjepit, desikator, cawan pengabuan, tanur (Branstead), Llyod Universal Testing Instrument, shaker water bath (Tecator), $\mathrm{pH}$ meter (Oacton), pompa vakum (Tecator), erlenmeyer, corong, gelas piala, pipet, Aw meter, piring kecil, nampan, dan borang.

\section{Tahapan Penelitian}

Proses pembuatan fruit leather pisang tanduk diawali dengan proses pembuatan puree pisang tanduk. Pisang tanduk yang akan dijadikan puree dipilih buah dalam kondisi baik, memiliki kulit buah berwarna kuning kecoklatan, daging buah berwarna putih kekuningan, beraroma kuat, dan tidak cacat. Pisang tanduk selanjutnya di steam (pengukusan) selama 10 menit. Selanjutnya pisang tanduk yang sudah di steam dihancurkan untuk mengecilkan ukuran dengan menggunakan blender dengan penambahan air selama 5 menit, sehingga didapatkan puree pisang tanduk.

Puree pisang tanduk selanjutnya ditambahkan gum arab $(0 \% ; 0,3 \% ; 0,6 \%$; dan $0,9 \%$ ), aquadest dan sorbitol. Kemudian campuran tersebut dihomogenkan selama 3 menit sampai semua bahan tercampur rata menjadi adonan puree pisang tanduk. Puree pisang tanduk yang telah dihomogenkan dengan bahan-bahan tambahan, selanjutnya dicetak dengan kedalam loyang berukuran $28 \times 28 \mathrm{~cm}$ yang telah dilapisi plastik poli etilen (PE) dengan ketebalan 0,8 $\mathrm{mm}$. 
Puree pisang tanduk yang telah dicetak kedalam loyang selanjutnya dikeringkan didalam cabinet dryer dengan suhu $70^{\circ} \mathrm{C}$ selama 16 jam. Fruit leather pisang tanduk dikeringkan hingga seluruh permukaannya kering, tidak mengkilap, dan tidak ada bagian yang lengket. Fruit leather yang telah kering kemudian dipotong-potong menjadi ukuran $4 \times 4 \mathrm{~cm}$ dan dikemas. Fruit leather pisang tanduk yang dihasilkan selanjutnya dianalisis karakteristik sensoris, kadar air, kadar abu, tekstur, aktivitas air (Aw), dan serat pangan.

\section{HASIL DAN PEMBAHASAN}

\section{A. Karakteristik Sensoris Fruit Leather Pisang Tanduk Dengan Penambahan Gum Arab}

Karakteristik sensoris yang diujikan meliputi parameter warna, aroma, rasa, tekstur, dan overall. Panelis diminta untuk menilai tingkat kesukaan dengan skor berdasarkan tingkat kesukaan panelis pada parameter yang telah ditentukan. Hasil penilalian selanjutnya dianalisa homogenitas dan perbedaannya melalui uji DMRT pada taraf kepercayaan $95 \%$. Hasil analisa tingkat kesukaan konsumen terhadap fruit leather pisang tanduk dapat dilihat pada Tabel 1.

\section{Warna}

Dari hasil analisis pada Tabel 1, fruit leather pisang tanduk dengan variasi konsentrasi penambahan gum arab menunjukkan ada perbedaan nyata antara fruit leather pisang tanduk yang tidak ditambahkan gum arab dengan fruit leather pisang tanduk yang ditambahkan dengan gum arab.

Berdasarkan hasil analisis semakin tinggi penambahan konsentrasi gum arab yang ditambahkan pada fruit leather pisang tanduk maka semakin tinggi tingkat kesukaan warna pada fruit leather pisang tanduk.

Warna fruit leather pisang tanduk yang disukai panelis adalah fruit leather pisang tanduk yang berwarna kuning kecokelatan dan cenderung cerah. Hal ini membuktikan bahwa semakin banyak penambahan gum arab maka warna fruit leather pisang tanduk yang dihasilkan semakin cerah. Gum arab yang baik memiliki warna orange kecokelatan (Toure, 2008).

\section{Aroma}

Pada Tabel 1. dapat dilihat hasil analisis tingkat kesukaan panelis terhadap parameter aroma fruit leather pisang tanduk. Untuk parameter aroma, fruit leather pisang tanduk dengan variasi konsentrasi penambahan gum arab menunjukkan tidak ada perbedaan nyata antara fruit leather pisang tanduk yang tidak ditambahkan gum arab dengan fruit leather pisang tanduk dengan variasi penambahan gum arab.

Gum arab berfungsi sebagai mikroenkapsulan atau bahan penyalut yang baik. Gum arab memiliki sifat yang baik untuk mempertahankan aroma pada fruit leather pisang tanduk (Glicksman, 1969). Gum arab tidak memiliki aroma sehingga penambahan gum arab tidak memberikan pengaruh yang berbeda terhadap aroma fruit leather pisang tanduk yang dihasilkan. Aroma fruit leather pisang tanduk yang disukai oleh panelis adalah fruit leather yang memiliki aroma khas pisang tanduk.

\section{Rasa}

Dari Tabel 1. parameter rasa tidak mengalami perbedaan nyata antara fruit leather pisang tanduk tanpa penambahan gum arab dengan fruit leather pisang tanduk dengan variasi penambahan konsentrasi gum arab. Rasa khas pisang tanduk lebih mendominasi pada rasa fruit leather pisang tanduk yang dihasilkan karena gum arab merupakan suatu komponen yang tidak memiliki rasa. Pada pembuatan fruit leather pisang tanduk ini juga ditambahkan sorbitol. Penambahan sorbitol tidak membuat rasa manis yang berlebihan pada fruit leather pisang tanduk yang dihasilkan. Rasa asam yang timbul pada fruit leather pisang tanduk memberikan efek asam yang menyegarkan dan menyeimbangkan rasa manis yang dihasilkan oleh pisang tanduk itu sendiri dan dari penambahan 
Tabel 1. Karakteristik Sensoris Fruit Leather Pisang Tanduk dengan Penambahan Gum Arab

\begin{tabular}{lcccc}
\hline Karakteristik & \multicolumn{4}{c}{ Konsentrasi Penambahan Gum Arab } \\
\cline { 2 - 5 } & $0 \%$ & $0,3 \%$ & $0,6 \%$ & $0,9 \%$ \\
\hline Warna & $3,17^{\mathrm{a}}$ & $3,47^{\mathrm{ab}}$ & $3,50^{\mathrm{ab}}$ & $3,73^{\mathrm{b}}$ \\
Aroma & $3,07^{\mathrm{a}}$ & $3,10^{\mathrm{a}}$ & $3,07^{\mathrm{a}}$ & $3,13^{\mathrm{a}}$ \\
Rasa & $3,43^{\mathrm{a}}$ & $3,53^{\mathrm{a}}$ & $3,80^{\mathrm{a}}$ & $3,80^{\mathrm{a}}$ \\
Tekstur & $2,63^{\mathrm{a}}$ & $3,00^{\mathrm{ab}}$ & $3,40^{\mathrm{bc}}$ & $3,60^{\mathrm{c}}$ \\
Overall & $3,23^{\mathrm{a}}$ & $3,37^{\mathrm{ab}}$ & $3,67^{\mathrm{b}}$ & $3,73^{\mathrm{b}}$ \\
\hline
\end{tabular}

Keterangan : 1. Sangat tidak suka, 2. Tidak suka, 3. Netral, 4. Suka, 5. Sangat suka notasi yang berbeda menunjukkan beda nyata pada taraf signifikansi $\alpha=0,05$

sorbitol. Rasa asam dihasilkan dari pisang tanduk yang mengandung asam organik. Secara keseluruhan fruit leather pisang tanduk yang dihasilkan memiliki rasa khas pisang tanduk yang kuat.

\section{Tekstur}

Dari data analisis yang diperoleh pada

Tabel 1. parameter tekstur terdapat perbedaan nyata antara fruit leather pisang tanduk tanpa penambahan gum arab dengan fruit leather pisang tanduk dengan penambahan gum arab $0,6 \%$ dan $0,9 \%$. Semakin besar penambahan konsentrasi gum arab maka semakin plastis tekstur fruit leather pisang tanduk yang dihasilkan. Penambahan gum arab menyebabkan tekstur fruit leather pisang tanduk semakin liat. Menurut panelis fruit leather pisang tanduk yang tidak ditambahkan gum arab memiliki tekstur yang keras dan kering sehingga sulit untuk dikunyah. Sedangkan fruit leather pisang tanduk dengan penambahan gum arab menurut panelis memiliki tekstur yang empuk dan lebih mudah dikunyah dibandingkan fruit leather pisang tanduk yang tidak diberi tambahan gum arab.

\section{Overall}

Dari Tabel 1. untuk parameter overall terdapat perbedaan nyata antara fruit leather pisang tanduk tanpa penambahan gum arab dengan fruit leather pisang tanduk dengan penambahan gum arab $0,6 \%$ dan $0,9 \%$. Sedangkan fruit leather pisang tanduk dengan penambahan gum arab sebanyak $0,3 \%$ tidak berbeda nyata dengan fruit leather pisang tanduk tanpa penambahan gum arab dan fruit leather pisang tanduk dengan penambahan gum arab dengan konsentrasi $0,6 \%$ dan $0,9 \%$. Tingkat penerimaan panelis terendah terdapat pda fruit leather tanpa penambahan gum arab yaitu sebesar 3,23. Sedangkan tingkat penerimaan panelis tertinggi terdapat pada fruit leather pisang tanduk dengan penambahan gum arab 0,9\% dengan nilai tingkat kesukaan sebesar 3,73. produk

\section{B. Karakteristik Fisik dan Kimia Fruit Leather Pisang Tanduk Dengan Penambahan Gum Arab}

Pengujian karakteristik fisik dan kimia pada fruit leather pisang tanduk dengan penambahan gum arab meliputi pengujian kuat tarik (tensile strength), kadar air, kadar abu, aktifitas air (Aw), dan serat pangan. Karakteristik fisik dan kimia pada fruit leather pisang tanduk dapat dilihat pada Tabel 2.

\section{Kuat Tarik (Tensile Strength)}

Kuat tarik dihitung berdasarkan gaya (Fmax) yang dibutuhkan untuk merenggangkan fruit leather pisang tanduk hingga terputus. Berdasarkan Tabel 2. kuat tarik fruit leather pisang tanduk dengan penambahan gum arab tidak berbeda nyata. Semakin besar penambahan konsentrasi gum arab maka semakin besar tingkat kuat tarik dari fruit leather pisang menjadi semakin baik.

Salah satu syarat fruit leather adalah memiliki tekstur plastis sehingga dapat digulung. Tekstur plastis pada fruit leather pisang tanduk dibentuk oleh proses pembentukan gel. Proses pembentukan gel dalam fruit leather terjadi selama proses pemanasan dengan adanya pektin, gula, asam, dan air (Desrosier, 1988).

Pada prinsipnya pembentukan gel terjadi karena adanya pembentukan jala atau jaringan tiga dimensi oleh molekul primer 
yang terentang pada seluruh volume gel yang terbentuk dengan merangkap sejumlah air didalamnya. Terjadi ikatan silang pada polimer-polimer yang terdiri dari molekulmolekul rantai panjang dalam jumlah yang cukup maka akan terbentuk bangunan tiga dimensi yang kontinyu sehingga terbentuk struktur yang kaku dan tegar yang tahan terhadap gaya maupun tekanan tertentu (Kennedy et al., 2011). Pembentukan gel oleh gum arab juga disebabkan karena panas, gel yang terbentuk teksturnya kenyal tetapi cukup lembut (Glicksman, 1969).

\section{Kadar Air}

Berdasarkan Tabel 2. variasi penambahan gum arab pada fruit leather pisang tanduk dengan konsentrasi $0,9 \%$ berbeda nyata dengan fruit leather pisang tanduk tanpa penambahan gum arab.

Berdasarkan penelitian yang dilakukan oleh Karyantina et al., (2012) kadar air pada fruit leather pisang dengan variasi suhu yaitu $25,85 \%$ sampai $52,91 \%$. Nilai ini lebih tinggi dibandingkan fruit leather pisang tanduk tanpa penambahan gum arab yang memiliki kadar air 13,775\%. Hal ini dapat disebabkan karena adanya perbedaan suhu dan waktu pengeringan.

Menurut Prasetyowati

penambahan gum arab akan meningkatkan total padatan pada fruit leather. Meningkatnya total padatan dalam produk, akan menurunkan persentase air yang terkandung dalam produk, sehingga kadar air mengalami penurunan dengan bertambahnya gum arab yang diberikan.

\section{Kadar Abu}

Berdasarkan Tabel 2, kadar abu pada fruit leather pisang tanduk dengan variasi konsentrasi penambahan gum arab tidak menunjukkan adanya perbedaan nyata antar sampel. Namun dengan adanya variasi konsentrasi penambahan gum arab, nilai kadar abu pada fruit leather pisang tanduk meningkat.

Pada penelitian Ni'mah (2013) kadar abu pada fruit leather pisang dengan penambahan rumput laut yaitu sebesar 1,6\%2,3\%. Nilai tersebut lebih rendah dibandingkian fruit leather pisang tanduk, hal ini disebabkan karena perbedaan varietas pisang yang digunakan dan juga adanya penambahan gum arab. Dari perbandingan data tersebut dapat diketahui penambahan gum arab berpengaruh pada peningkatan kadar abu pada fruit leather pisang tanduk yang dihasilkan.

Pada gum arab terkandung garam mineral seperti kalsium, magnesium, dan potassium yang berasal dari asam polisakarida. Kandungan abu pada dalam gum arab dengan kualitas yang baik yaitu < 4\% (Glicksman, 1969). Sedangkan kadar abu pada pisang sebesar 0,68\%-0,80\% (Adeyemi dan Oladiji, 2009).

\section{Aktivitas Air (Aw)}

Berdasarkan Tabel 2. nilai Aw pada fruit leather pisang tanduk tidak ada perbedaan nyata. Selain itu nilai Aw tidak mengalami perubahan. Kadar Aw turun menjadi 0,54 pada fruit leather pisang tanduk dengan penambahan gum arab sebanyak $0,9 \%$.

Pada penelitian ini menggunakan pemanis yaitu sorbitol. Sorbitol sebagai humektan yang merupakan agensia pengikat air dalam makanan atau air bebas yang terdapat dalam bahan diikat oleh sorbitol (Murni, 2010).

Nilai Aw pada fruit leather pisang tanduk antara 0,54-0,56 menunjukkan bahwa fruit leather pisang tanduk memiliki nilai Aw yang rendah dibandingkan nilai Aw untuk syarat pertumbuhan bakteri, kapang, ataupun khamir. Hal ini juga menunjukkan bahwa umur fruit leather pisang tanduk memiliki umur simpan yang panjang. Selain hal tersebut, pengemasan yang baik juga menjadi faktor untuk mempertahankan nilai Aw pada fruit leather pisang tanduk.

\section{Serat Pangan}

Hasil analisis serat pangan fruit leather pisang tanduk dengan penambahan gum arab dapat dilihat pada Tabel 2.

Fruit leather pisang tanduk kandungan serat berasal dari pisang tanduk dan gum arab. Semakin tinggi konsentrasi penambahan gum arab menyebabkan kandungan serat pangan dalam fruit leather pisang tanduk semakin meningkat. 
Tabel 2. Karakteristik Fisik dan Kimia Fruit Leather Pisang Tanduk dengan Penambahan Gum Arab

\begin{tabular}{lcccc}
\hline Karakteristik & \multicolumn{4}{c}{ Konsentrasi Penambahan Gum Arab } \\
\cline { 2 - 5 } & $0 \%$ & $0.3 \%$ & $0.6 \%$ & $0.9 \%$ \\
\hline Kuat tarik (N) & $4,8449^{\mathrm{a}}$ & $5,8037^{\mathrm{a}}$ & $6,5440^{\mathrm{a}}$ & $5,8125^{\mathrm{a}}$ \\
Kadar air \% (wb) & $13,775^{\mathrm{b}}$ & $13,564^{\mathrm{ab}}$ & $13,349^{\mathrm{ab}}$ & $12,696^{\mathrm{a}}$ \\
Kadar abu \% (db) & $2,857^{\mathrm{a}}$ & $2,870^{\mathrm{a}}$ & $2,894^{\mathrm{a}}$ & $2,896^{\mathrm{a}}$ \\
Aktivitas air (Aw) & $0,56^{\mathrm{a}}$ & $0,56^{\mathrm{a}}$ & $0,56^{\mathrm{a}}$ & $0,54^{\mathrm{a}}$ \\
Serat pangan \% (db) & $2,7563^{\mathrm{a}}$ & $4,1435^{\mathrm{b}}$ & $4,7771^{\mathrm{c}}$ & $5,0825^{\mathrm{c}}$ \\
\hline Keterangan notasi yang berbeda menunjukkan beda nyata pada taraf signifikansi $\alpha=0,05$ &
\end{tabular}

Tabel 3. Data Rekomendasi Konsentrasi Penambahan Gum Arab Pada Fruit Leather Pisang Tanduk

\begin{tabular}{|c|c|c|c|c|}
\hline \multirow[t]{2}{*}{ Parameter } & \multicolumn{4}{|c|}{ Konsentrai Penambahan Gum Arab } \\
\hline & $0 \%$ & $\mathbf{0 , 3 \%}$ & $0,6 \%$ & $\mathbf{0 , 9 \%}$ \\
\hline Warna* & $3,17^{\mathrm{a}}$ & $3,47^{\mathrm{ab}}$ & $3,50^{\mathrm{ab}}$ & $3,73^{b}$ \\
\hline Aroma* & $3,07^{\mathrm{a}}$ & $3,10^{\mathrm{a}}$ & $3,07^{\mathrm{a}}$ & $3,13^{\mathrm{a}}$ \\
\hline Rasa* & $3,43^{\mathrm{a}}$ & $3,53^{\mathrm{a}}$ & $3,80^{a}$ & $3,80^{\mathrm{a}}$ \\
\hline Tekstur* & $2,63^{\mathrm{a}}$ & $3,00^{\mathrm{ab}}$ & $3, \mathbf{4 0} 0^{b c}$ & $3,60^{\mathrm{c}}$ \\
\hline Overall* & $3,23^{\mathrm{a}}$ & $3,37^{\mathrm{ab}}$ & $3,67^{b}$ & $3,73^{b}$ \\
\hline Kuat tarik $(\mathrm{N})$ & $4,8449^{\mathrm{a}}$ & $5,8037^{\mathrm{a}}$ & $6,5440^{\mathrm{a}}$ & $5,8125^{\mathrm{a}}$ \\
\hline Kadar air \% (wb) & $13,775^{\mathrm{b}}$ & $13,564^{\mathrm{ab}}$ & $13,349^{\mathrm{ab}}$ & $12,696^{\mathrm{a}}$ \\
\hline Kadar abu \% (db) & $2,857^{\mathrm{a}}$ & $2,870^{\mathrm{a}}$ & $2,894^{\mathrm{a}}$ & $2,896^{\mathrm{a}}$ \\
\hline Aktivitas air (Aw) & $0,56^{\mathrm{a}}$ & $0,56^{\mathrm{a}}$ & $0,56^{\mathrm{a}}$ & $0,54^{\mathrm{a}}$ \\
\hline Serat pangan $\%(\mathrm{db})$ & $2,7563^{\mathrm{a}}$ & $4,1435^{\mathrm{b}}$ & $4,7771^{c}$ & $5,0825^{\mathrm{c}}$ \\
\hline
\end{tabular}

\section{Rekomendasi}

Berdasarkan analisis sensoris, fisik, dan kimia yang dilakukan pada fruit leather pisang tanduk dengan penambahan gum arab maka diperoleh konsentrasi penambahan gum arab yang terbaik secara sensoris maupun fisik dan kimia. Tabel $\mathbf{3}$ menujukkan data rekomendasi konsentrasi gum arab dalam pembuatan fruit leather pisang tanduk yang paling efektif dan disukai oleh panelis. Berdasarkan Tabel $\mathbf{3}$ dapat dilihat karakteristik sensoris maupun fisik dan kimia fruit leather pisang tanduk direkomendasikan fruit leather dengan penambahan gum arab dengan konsentrasi $0,6 \%$.

\section{KESIMPULAN}

Berdasarkan penelitian yang telah dilakukan untuk mengkaji karakteristik sensoris, fisik, dan kimia fruit leather pisang tanduk dengan penambahan gum arab dapat diambil kesimpulan antara lain :
1. Berdasarkan karakteristik sensoris fruit leather pisang tanduk, penambahan gum arab dengan konsentrasi $0,3 \%, 0,6 \%$, dan $0,9 \%$ berpengaruh nyata pada parameter warna, tekstur, dan overall. Sedangkan penambahan gum arab pada parameter aroma dan rasa fruit leather pisang tanduk yang dihasilkan tidak memberikan pengaruh yang nyata.

2. Berdasarkan karakteristik fisik dan kimia, penambahan gum arab pada fruit leather pisang tanduk berpengaruh nyata terhadap kadar air dan serat pangan (dengan kisaran kadar air 12,696\%-13,775\% (wb) dan serat pangan $2,7563 \% \quad-5,0825 \%(\mathrm{db}))$. Selebihnya penambahan gum arab hingga konsentrasi $0,9 \%$ tidak berpengaruh nyata terhadap kadar abu, aktivitas air (Aw) dan kuat tarik fruit leather pisang tanduk.

3. Berdasarkan karakteristik sensoris, fisik, maupun kimia fruit leather pisang tanduk direkomendasikan konsentrasi penambahan gum arab sebesar $0,6 \%$. 


\section{SARAN}

Berpedoman pada hasil penelitian yang telah diperoleh maka disarankan adanya penelitian lanjutan terhadap penggunaan gum arab dengan konsentrasi yang lebih tinggi. Disarankan untuk menggunakan alat pencetak untuk menyeragamkan ketebalan fruit leather pisang tanduk yang dihasilkan. Selain itu juga disarankan adanya uji sineresis untuk mengetahui ada tidaknya peristiwa sineresis pada fruit leather pisang tanduk

\section{DAFTAR PUSTAKA}

Adeyemi, O. S. dan, A. T. Oladiji. 2009. Compositional Changes In Banana (Musa ssp.) Fruits During Repening. African Journal of Biotechnology. Vol. 8 (5). Page. 858-859.

Ambarsari, Indrie, Qanytah, dan Sarjana. 2005. Penerapan Standar Penggunaan Pemanis Buatan Pada Produk Pangan . Balai Pengkajian Teknologi Pertanian Jawa Tengah.

Asben, A. 2007. Peningkatan Kadar Iodium dan Serat Pangan dalam Pembuatan Fruit Leathers Nenas (Ananas comosus Merr) dengan Penambahan Rumput Laut. Artikel Ilmiah Penelitian Dosen Muda. Universitas Andalas. Padang.

Asp, N.G, C.G. Johanson, H. Halmer, dan M. Sijelstrom. 1983. Rapid Enzymatic Assay of Insoluble and Soluble Dietary Fiber. J. Agric. Food. Chem. Vol 31. Page 476482.

Aviany, T. P. 2013. Kajian Karakteristik Fisikokimia dan Sensoris Fruit Leather Nangka (Artocarpus heterophyllus) dengan Penambahan Gum Arab Sebagai Upaya Diversifikasi Pangan. Skripsi Fakultas Pertanian. Universitas Sebelas Maret. Surakarta.

Azeredo, H. M. C, E. S. Brito, G. E. G Moreira, V. L. Farias, dan L. M. Bruno. 2006. Effect Of Drying And Storage Time On The Physico-Chemical Properties Of Mango Leathers. International Journal of Food Science and Technology. Vol. 41 Page. 635-638.
Badan Pusat Statistik. 2012. Produktivitas Buah-Buahan Tropis Indonesia. www.bps.go.id. Diakses pada 26 November 2013.

Cahyono, B. 1995. Pisang Budidaya dan Analisis Usaha Tani. Kanisius. Yogyakarta.

Deman, J. M. 1997. Kimia Makanan. Penerbit ITB. Bandung.

Departemen Pertanian. 2011. Konsumsi Buah-Buahan di Indonesia. http:// hortikultura.deptan.go.id. Diakses pada 26 November 2013.

Desrosier, N. 2008. Teknologi Pengawetan Pangan. Penerbit Universitas Indonesia. Jakarta.

Direktorat Pengolahan dan Pemasaran Hasil Hortikultura. 2004. Pisang. Buletin Teknopro Hortikultura. Edisi 72.

Dwiyana, D. R. 2011. Perbandingan Konsentrasi Hidrokoloid Dan Konsentrasi Asam Sitrat Dalam Minuman Jeli Susu Sesuai Mutu Dan Kualitas. Skripsi Fakultas MIPA Univeritas Pakuan. Bogor.

Glicksman, M. 1969. Gum Technology In The Food Industry. Academic Press Inc. New York.

Historiarsih, R. Z. 2010. Pembuatan Fruit Leather Sirsak-Rosella. Skripsi Program Studi Ilmu dan Teknologi Pangan Fakultas Teknologi Industri UPN "Veteran". Surabaya.

Karki, M. 2011. Evaluation of Fruit Leathers Made From New Zealand Grown Blueberries. Thesis at Lincoln University. New Zealand.

Karyantina, M., L. Kurniawati, dan A. S. Wardana. 2010. Kajian Karakteristik Fruit Leather Dengan Variasi Jenis Pisang (Musa paradisiaca) dan Suhu Pengeringan. Fakultas Teknologi dan Industri Pangan Universitas Slamet Riyadi. Surakarta.

Kennedy, J. F, G. O. Phillips, dan P. A. Williams. 2011. Gum Arabic. Royal Society of Chemistry. 
Kuntarsih, S. 2012. Pedoman Penanganan Pascapanen Pisang. Departemen Pertanian. Jakarta.

International Diabetes Federation. 2013. Diabetes in Indonesia-2013. www.idf.org. Diakses pada 20 Febuari 2014.

Latifah, R. Nurismanto, dan C. Agniya. 2013. Pembuatan Selai Lembaran Terong Belanda. FTI UPN "Veteran". Jawa Timur.

Legowo, A. M. dan Nurwanto. 2004. Analisis Pangan. Diktat Kuliah. Fakultas Peternakan. UNDIP. Semarang.

Mitchell, H. 2006. Sweeteners and Sugar Alternative In Food Technology. Black Well Publishing LTD. United Kingdom.

Mohapatra, D., S. Mishra, dan N. Sutar. 2010. Banana and Its By-Product Utilisation : An Overvie. Journal of Scientific and Industrial Researsch. Vol. 69. Page 323-329.

Muchtadi, T. R dan F. Ayustaningwarno. 2010. Teknologi Proses Pengolahan Pangan. Penerbit Alfabeta. Bandung.

Mulyati, S., I, Baskhara, dan L. T. Dewi. 2012. Teknologi Pengolahan Pangan Teknologi Pengolahan Buah dan Sayur Fruit Leather Sirsak (Annona Muricata L.) Teknologi Pengolahan Buah dan Sayur.

Ni'mah, A. M. 2013. Kajian Karakteristik Kimia dan Sensoris Fruit Leather Beberapa Varietas Pisang (Musa spp.) dengan Variasi Penambahan Rumput Laut (Kappaphycus alvarezii). Skripsi. Program Studi Ilmu dan Teknologi Pangan. UNS. Surakarta.

Okilya, S, I. M. Mukisa, dan A.N. Kanya. 2010. Effect Of Solar Drying On The Quality And Acceptability Of Jackfruit Leather. EJEAFChe. Uganda.

Prasetyowati, D. A. 2014. Pengaruh Penambahab Gum Arab Terhadap Karakteristik Fisikokimia dan Sensoris Fruit Leather Nanas (Ananas comosus L. Merr.) dan Wortel (Daucus carota). Skripsi. UNS. Surakarta.
Puspasari, K. 2007. Aplikasi Teknologi Dan Bahan Tambahan Pangan Untuk Meningkatkan Umur Simpan Mie Basah Matang. Skripsi Fakultas Teknologi Pangan IPB. Bogor.

Rahmi, N. 1996. Kajian Proses Pembuatan Permen Jelly Jahe. Skripsi. Fakultas Teknologi Pertanian. IPB. Bogor.

Rismunandar. 1981. Bertanam Pisang. CV Sinar Baru. Bandung.

Syamsir, E. 2011. Learn Everything About Dietary Fiber. Ilmupangan.blogspot.com. Diakses pada 8 Juli 2014.

Santoso, A. 2011. Serat Pangan (Dietary Fiber) dan Manfaatnya Bagi Kesehatan. Magistra. No. 75.

Satuhu, S dan A, Supriyadi. 1999. Pisang Budidaya, Pengolahan, dan Prospek Pasar. Penebar Swadaya. Jakarta.

Setyaningsih, D, et al. 2010. Analisis Sensoris Untuk Industri Pangan dan Agro. IPB Press. Bogor

Setyawan, Ari. 2007. Gum Arab. Alumni Jurusan Teknologi Hasil Pertanian Universitas Brawijaya. Diakses pada 26 November 2013.

Shafi'i, S. N, A. Noorlaila, A. M. Zahid, H. N. Mohd; dan I. Normah. 2013. Optimization of Hydrocolloids and Maltodextrin Addition on Roselle-Based Fruit Leather Using Two-Level Full Factorial Design. International Journal of Bioscience, Biochemistry And Bioinformatics. Vol. 3. No. 4

Sudarmadji, S, B. Haryanto, dan Suhardi. 1997. Analisa Bahan Makanan dan Pertanian. Liberty. Yogyakarta.

Sumaryati, E. 2005. Pembuatan Leather Mengkudu ( Morinda Cintrifolia ) Kajian Lama Perendaman Dan Konsentrasi Larutan Kapur Terhadap Kualitas Leather Mengkudu Yang Dihasilkan. Fakultas Pertanian Univ. Widyagama Malang.

Syafutri, M. I, L. Eka, I. Hendra. 2010. Karakteristik Permen Jelly Timun Suri (Cucumis Melo L.) Dengan Penambahan Sorbitol Dan Ekstrak Kunyit (Curcuma 
Domestika Val.). Jurnal Gizi dan Pangan. Vol. 5. No. 2.

Torio, M.A.O., J. Saez, dan F. E. Merca. 2006. Physcochemical Characterization of Galactomannan from Sugar Palm (Arenga saccharifea Labill.) Endosperm at Different Stages of Nut Maturity. Philippine Journal of Science. Vol. 135. Page 19-30.

Yuniwati, M., D. Ismayati, dan R. Kurniasih. 2011. Kinetika Reaksi Hidrolisis Pati Pisang Tanduk Dengan Katalisator Asam Chlorida. Jurnal Teknologi, Vol. 4 No. 2, hal 107-112.

Yenrina, R, H. Nurhaida; dan Z. Rika. 2009. Mutu Selai Lembaran Campuran Nenas (Ananas Comusus) Dengan Jonjot Labu Kuning (Cucurbita Moschata). Jurnal Pendidikan dan Keluarga UNP. Vol. 1. No. 2.

Zubaidah, E., Saparianti, E., Mawardhani, M. (2005). Peranan Substitusi dengan Sari Wortel dan Kondisi Fermentasi terhadap Karakteristik Minuman Susu Terfermentasi Bakteri Asam Laktat. Jurnal Teknologi Pertanian, Vol. 6 No.2 hal. 93100. Unibraw. Malang. 